Page 1 of 16

\title{
A 'British' Silurian crinoid from Quinn Point, New Brunswick, eastern \\ Canada
}

Stephen K. Donovan ${ }^{\mathrm{a},}{ }^{*}$, David G. Keighley ${ }^{\mathrm{b}}$

${ }^{a}$ Department of Geology, Naturalis Biodiversity Center, Darwinweg 2, 2333 CR Leiden, The Netherlands

${ }^{\mathrm{b}}$ Department of Earth Sciences, University of New Brunswick, Fredericton, New Brunswick, Canada E3B $5 A 3$

ARTICLE INFO

Article history:

Received 8 November 2014

Keywords:

Cyclocyclicus

Lanxocolumnus

Systematics

Palaeogeography

Pseudolumen

lapetus Ocean

* Corresponding author. Tel. +31 715687642

E-mail address: Steve.Donovan@naturalis.nl (S.K. Donovan) 
Page 2 of 16

ABSTRACT

Crinoids are common fossils, yet complete specimens are rare. Diverse plates from the crinoid endoskeleton may be preserved, but the columnals from the stem are the most common. Even if not distinct enough to assign to a known group, they may be classified within columnal morphotaxa. Currently, identification of distinctive columnals is adding diversity to the Silurian biota. Lanxocolumnus (col.) chaleurensis sp. nov. is a heteromorphic crinoid column from the upper Llandovery (Telychian) of Quinn Point, Chaleur Bay, New Brunswick, eastern Canada. It has large and distinctive nodals and high-order internodals, with smooth and discoid epifacets. The articular facets are sunken and nodals(?) have a unique feature, a circular pseudolumen into which a small internodal lacking an epifacet may fit. The lumen/axial canal sensu stricto is narrow, central and rounded to (commonly) pentastellate. This Canadian species is closely related to Lanxocolumnus (col.) geoffnewalli (Fearnhead and Donovan) comb. nov. from Shropshire, England. This is a further example of a crinoid taxon that migrated from Laurentia to Avalonia as the lapetus Ocean closed.

\section{Introduction}

Crinoids first appeared in the Early Ordovician (Guensburg and Sprinkle, 2003) and persist to the present day, but their fossil remains are most common in the post-Cambrian Palaeozoic. The fossil record of the crinoids is controlled by the taphonomy of the multi-plated endoskeleton. Like other echinoderms, crinoids had, and have, an internal skeleton composed of numerous calcite plates, or ossicles, that are held together by unmineralized tissues. Following death, these soft tissues decompose and individual plates are released into the sedimentary environment, except in examples where adjacent ossicles are locked together by intergrowths of their calcitic skeleton 
(Donovan, 1991, fig. 11.2C). These disarticulated plates are commonly encountered in the rock record.

It is this common preservation as ossicles that has biased our conception of the history of the crinoids, whose classification is strongly dependent upon well preserved specimens. These specimens are rare except in Echinodermen-Lagerstätten, such as starfish beds, in which the exceptional complete preservation is the result of rapid burial, arrested decay or a combination of these and other factors (Donovan, 1991). For example, a well-known Echinodermen-Lagerstätte in the Silurian of the British Isles is the Much Wenlock Limestone Formation at the Wrens Nest, Dudley, which has yielded over 60 nominal species of well-preserved crinoids (Donovan et al., 2009, 2010, 2012) and other fine fossils.

New Brunswick in eastern Canada has broad outcrops and locally good exposures of fossiliferous, marine, Silurian sedimentary rocks, but no Echinodermen-Lagerstätte has been identified. The study of crinoids from this province has thus languished without a Dudley to inspire research. The present contribution is part of an ongoing programme to compare the Silurian crinoids of New Brunswick with those of the British Isles. An initial report has already described Scyphocrinites sp. from west of Campbellton, northern New Brunswick (Donovan and Miller, 2014), a genus that is an international marker for the Silurian-Devonian transition. In the present paper we identify an older crinoid related to the English Telychian morphospecies Cyclocyclicus (col.) geoffnewalli Fearnhead and Donovan, 2007. The new Canadian specimens are from east of the Scyphocrinites locality (Fig. 1). This morphospecies, based on distinctive columnals, is similar to a coeval species described from the Llandovery of Shropshire; herein, we discuss their systematic position and palaeogeographic significance.

Terminology of the crinoid endoskeleton follows Moore et al. (1978), Ubaghs (1978) and Webster (1974). Specimens discussed herein are deposited in the Naturalis Biodiversity Center, Leiden, the Netherlands (specimen numbers prefixed by RGM). 


\section{Locality and horizon}

The Silurian crinoid radiation, following the end-Ordovician extinction event, has now been well documented in Llandovery strata from lowa and Ohio, through New York, into Ontario and Anticosti Island (Québec) Canada, and across to the British Isles and Ireland (Donovan, 1994; Ausich and Deline, 2012). One of the remaining gaps in the database is the Silurian strata around the coast of Chaleurs Bay in the Gaspé (southern mainland Québec) and northern New Brunswick, where crinoid material has often been noted, but rarely identified.

Silurian strata outcrop widely in northern New Brunswick and the adjacent southern Gaspé Peninsula. West of Campbellton and north into Gaspé (Fig. 1), the succession (Chaleurs Group) is deemed continuous (Bourque et al., 2001). South and east of Campbellton, there is evidence of potentially three unconformities in the Silurian record. These three structures are interpreted as relating to tectonism associated with the 440-422 Ma Salinic orogenic convergence and oblique collision of Ganderia with Laurentia, prior to the accretion of Avalonia in New Brunswick at $420-$ 390 Ma (Van Staal et al., 2009; Wilson and Kamo, 2012). According to the latter authors, strata previously assigned to the Chaleurs Group in the study area, between Trapp Point and Little Belledune Point (Fig. 1B), are now placed into the unconformity-bound Quinn Point Group and overlying unconformity bound Dickie Cove Group. The Quinn Point Group in the study area (the type section) consists of a basal conglomerate conformably overlain by greenish-grey to black calcareous sandstones and siltstones, and fossiliferous, massive and nodular limestones. It is the latter limestones at Quinn Point that yielded the specimens described below.

The La Vieille Formation was first introduced in Gaspé for the entire aforementioned succession, with older siliciclastics assigned to the Clemville Formation (Schuchert and Dart, 1926; Bourque, 1975). The La Vieille Formation was first adopted in New Brunswick by Alcock (1935, pp. 32-44), who noted the presence of large crinoid columns both along the coast near Culligan and 
Page 5 of 16

again due south in railway cuttings (Fig. 1B). The formation name was later restricted to the limestone part of the succession in Gaspé (Northrop, 1939; Bourque, 1975), with the Weir Formation introduced for the basal conglomerates (Ayrton, 1967; Bourque, 1975). In the Quinn Point - Culligan area, Howells (1975) noted crinoid ossicles at several horizons in the limey, clastic, transgressive shoreface Clemville Formation, as well as an encrinite facies near the base of the La Vieille Formation and marking the time of maximum transgression. Subsequently, Noble (1976) introduced the Armstrong Brook Formation for the conglomerates in New Brunswick, and the Limestone Point Formation for the calcareous sandstone and crinoid ossicle-bearing limestone, while retaining the La Vieille Formation for the overlying nodular and highly fossiliferous limestone. Noble and Howells (1979) revised the biofacies in the Limestone Point Formation at Quinn Point. Walker and McCutcheon (1995) noted that the Limestone Point Formation was often not mappable at 1:20,000 and relegated the unit to a member of the La Vieille Formation, while also abandoning the Armstrong Brook Formation in favour of the Weir Formation. The latest 1:50,000 provincial geology map covering the study area (Wilson, 2013) shows only the La Vieille Formation, although the Limestone Point Formation (retained in its original intent by Wilson and Kamo, 2012) is present on the coast.

The Quinn Point Group is considered of Telychian to Sheinwoodian in age based on fossil control. In particular, Howells (1975) noted the upper Limestone Point Formation and base La Vieille Formation contains Llandoverian C6 brachiopods (Eocoelia sulcata), whereas Nowlan (1983) identified C5-C6 conodonts and Costistricklandia beds at the base of the La Vieille Formation, suggesting early Wenlock strata at the top.

\section{Materials and methods}


Crinoid columnals and pluricolumnals were photographed in the field (Fig. 2) and a sample of well-preserved specimens collected for photography in the laboratory, coated by ammonium chloride (Fig. 3). Specimens required no cleaning or other preparation. All specimens were photographed without further preparation using a Canon PowerShot G11 digital camera. The description was written with reference to Fearnhead (2008). Twenty specimens were collected, registered as RGM 791782 to 791800 .

\section{Systematic palaeontology}

Class Crinoidea J.S. Miller, 1821

Subclass Camerata(?) Wachsmuth and Springer, 1885

Incerti ordinis

Morphogenus Lanxocolumnus (col.) Donovan, 1995

Type morphospecies: Lanxocolumnus (col.) quinquelateralis Donovan, 1995, p. 139, pl. 22, figs. 1-4, by original designation, from the Upper Ordovician (Katian [=Caradoc; Fortey et al., 2000, fig. 24], clingani Biozone; Mohibullah et al., 2014, text-fig. 2) of the Craighead Limestone Formation, Craighead Inlier, Ardmillan Group, Strathclyde, south-west Scotland.

Diagnosis: (Slightly modified after Donovan, 1995, p. 138.) Pentagonal to circular columnals with a pentagonal to circular (uncommonly elliptical) articular facet. Lumen central, opposed, either pentagonal, pentalobate or pentastellate in outline. Articulation is symplectial, with fine crenulae developed on the articular facet and more massive crenulae(?) uncommonly occurring on the epifacet of nodals at the internodal angles. Columnal and lumen angles rounded. Column heteromorphic. Nodals and high order internodals with more or less swollen epifacets.

Remarks: This is the first record of Lanxocolumnus (col.) from the Silurian of Laurentia. 
Range: Upper Ordovician (Katian) of south-west Scotland; Lower Silurian (Llandovery, Telychian) of New Brunswick, Canada, and Shropshire, England; and, less certainly, Lower Carboniferous (Mississippian, Brigantian $\left(D_{2}\right)$, Viséan) of Derbyshire, England (Donovan, 1995; Fearnhead and Donovan, 2007 (as Cyclocyclicus); Bouman and Donovan, in review; herein).

Lanxocolumnus (col.) chaleurensis sp. nov. (Figs. 2, 3)

Etymology: After the type locality on Chaleur Bay (Fig. 1).

Material: Twenty specimens, RGM 791782 to 791 799, 791800 (two separate columnals), plus many more left in the field (for example, Fig. 2A).

Locality and horizon: Coastal exposure at Quinn Point, about $7 \mathrm{~km}$ west of Belledune, north New Brunswick, eastern Canada. Vertical limestones of the Limestone Point Formation, Quinn Point Group (see above). Silurian, Llandovery, Telychian.

Diagnosis: Xenomorphic crinoid columns; nodals and high-order internodals with broad, inflated, flanged epifacets; articular facet in deep depression; small, circular internodals in pseudolumen in nodal; true lumen small, central, rounded to stellate; articulation symplectial.

Description: Columnals locally common (Fig. 2A), presumed nodals and high order internodals (Figs 2C, 3D), circular in outline and discus-like, except RGM 791784 (Fig. 3C) which shows a lobate outline on one side only. Articular facet circular, depressed, central and small (Figs. 2B, E, 3A-C, E-G), with a narrow marginal symplexy of short, unbranched crenulae; broad, circular areola; and a small, circular to pentastellate lumen (Figs. 2B, E, 3C, E, F). The lumen is apparent on small internodals, dislodged in one specimen (Fig. 3C), which, when missing leaves a circular opening, named herein a pseudolumen (Fig. 3G; see Discussion). Larger internodals, but without latera (tertinternodals or lower orders) may be preserved in the depression of the articular facet (Fig. 3F). Epifacet broad, swollen, unsculptured, more or less inflated, with an angular to more rounded circumference at midheight. 
Pluricolumnals heteromorphic. Nodals, priminternodals and secundinternodals each with a broad epifacet (Figs. 2C, 3D), nodals highest et seq. These higher order columnals separated by narrower, regularly arranged internodals lacking epifacets (not seen in pluricolumnals, where they are concealed by limestone, but see Fig. 3F). The column is thus N?2?1?2?, where '?' signifies one or (probably) more small internodals.

Crown unknown, but smooth internal surface of moderately large pentagonal basal(?) plate seen in the field (Fig. 2D).

\section{Discussion}

Lanxocolumnus (col.) has been identified in one site only, the Upper Ordovician limestones of the Craighead Quarry in the Craighead Inlier, south-west Scotland (Donovan, 1995), with a single exception (Lanxocolumnus? (col.) sp.) from the Mississippian of Derbyshire (Bouman and Donovan, in review). Increasing the range into the Telychian of New Brunswick is thus an extension in both time and space. The morphology of the Lanxocolumnus (col.) nodal and higher order internodals is distinctive, with a sunken articular facet and broad epifacet. Only internodals without an epifacet could articulate with such a columnal. As such, it is reminiscent of Llandovery Floricolumnus (col.) Donovan and Clark, 1992 (see Donovan et al., 2012, pp. 225-228, text-figs. 99, 100, pl. 38, fig. 2), although the articular facet in that morphogenus is conical and the highly ornate epifacet contrasts with the simple outlines of Lanxocolumnus (col.) spp. The one specimen in the present sample with a more lobate outline (Fig. 3C) may be partially regenerated after being bitten by a predator or otherwise damaged.

The structure that we have named the pseudolumen herein is a morphological feature hitherto unrecognized in the crinoid stem. It is a central in the sunken articular facet of a columnal with an epifacet, possibly only nodals (but it may also occur in high order internodals; Fig. 3G), into 
which a small internodal fits precisely (Fig. 3C). The lumen sensu stricto, that is, the expression of the axial canal on the articular facet, is found in the centre of this small internodal that fills the pseudolumen so precisely. Adjacent, sequential internodals are broader and are as wide as the depressed articular facet of the large columnal (Fig. 3F). The functional and developmental implications of this unexpected arrangement of columnals can only be speculative and are unlikely to be solved without a large sample of Lanxocolumnus (col.) pluricolumnals for serial sectioning. These columnals and pluricolumnals appear to be closely similar to Lanxocolumnus (col.) geoffnewalli (Fearnhead and Donovan, 2007) comb. nov. from the Telychian of Shropshire, England (Fig. 4). The original identification of the English columnals as Cyclocyclicus (col.) was due to the poor preservation of the (abundant) specimens as external moulds in medium-grained sandstones. This made the area of the articular facet, as is so well seen in the New Brunswick specimens, appear to be a broad lumen (Fig. 4B; see Fearnhead and Donovan, 2007, p. 341, fig. 2), as it does in specimens in the present study in which the central, depressed articular facet of the New Brunswick species is occluded by limestone (Fig. 3A, B). That the lumen was actually much narrower was hinted at by one specimen (RGM 211 636; Fearnhead and Donovan, 2007, fig. 5A) in which the infill of a narrow axial canal is similar to that of $L$. (col.) chaleurensis. As seen in the Shropshire species, it is probable that there were cryptic internodals hidden within the column, although impossible to prove on such mouldic specimens. Lanxocolumnus (col.) geoffnewalli is distinguished from L. (col.) chaleurensis principally in having nodals with rounded latera, and prim- and secundinternodals with planar latera (Fig. 4A). Such internodals in depressed articular facet preservation is common in specimens from the Upper Ordovician of Scotland (e.g., Donovan, 1995, pls. 22, 23).

Although classified as a morphogenus, Lanxocolumnus (col.) spp. shows such a unique suite of morphological features that they must form part of a natural group at the level of genus or family. Quite possibly they are derived from a crinoid taxon that is well known from features of the crown. These specimens are too robust to have been disparids, which are gracile, or flexible cladids, which 


\section{Page 10 of 16}

have a distinctive and different morphology to the column. Therefore, they are most likely either a cladid (excluding the flexibles) or a camerate.

In the Ordovician-Silurian the lapetus Ocean was closing and faunas on either side were becoming increasingly similar due to migration (McKerrow and Cocks, 1976; Torsvik and Cocks, 2013). Certainly, the Silurian crinoids from both sides of the lapetus Suture have long been recognised as becoming increasingly similar from the Ordovician to Silurian (Sevastopulo in Holland, 1971; Donovan, 1989). Lanxocolumnus (col.) provides a further example of a crinoid taxon that migrated across the shrinking lapetus Ocean. The earliest Lanxocolumnus (col.) are from the Katian (Late Ordovician) of Scotland, that is, they are Laurentian (Torsvik and Cocks, 2013, fig. 2.15). The lapetus Ocean had essentially closed by the Telychian (Torsvik and Cocks, 2013, fig. 2.17) and by this time Lanxocolumnus (col.) is known from both sides of the suture, in Avalonian Shropshire and Laurentian-Ganderian New Brunswick.

\section{Acknowledgements}

S.K.D. gratefully acknowledges the support of the Naturalis Biodiversity Center, Leiden, for facilitating his research visit to the University of New Brunswick in May 2014. D.G.K. thanks Reg Wilson (New Brunswick Department of Energy and Mines) for introducing him to the Silurian of the region. We thank Dr. Fiona E. Fearnhead (the Natural History Museum, London) and Mr. Jeffery R. Thompson (University of Southern California, Los Angeles) for their perspicacious reviews.

\section{References}




\section{Page 11 of 16}

Alcock, F.J., 1935. Geology of Chaleurs Bay region. Geological Survey of Canada, Memoir 183, 146 pp.

Ausich, W.I., Deline, B., 2012. Macroevolutionary transition in crinoids following the late Ordovician extinction event (Ordovician to early Silurian). Palaeogeography, Palaeoclimatology, Palaeoecology 361/362, 38-48.

Ayrton, W.G., 1967. Chandler - Port-Daniel area. Quebec Department of Natural Resources, Geologic Report 120, 91 pp.

Bouman, R.W., Donovan, S.K., (in review). Biodiversity of Mississippian (Lower Carboniferous) crinoids from Bradford Dale, Derbyshire. Proceedings of the Yorkshire Geological Society.

Bourque, P.-A., 1975. Lithostratigraphic framework and unified nomenclature for Silurian and basal Devonian rocks in eastern Gaspé Peninsula, Québec. Canadian Journal of Earth Sciences 12, $858-872$.

Bourque, P.-A., Kirkwood, D., Malo, M., 2001. Stratigraphy, tectono-sedimentary evolution and paleogeography of the post-Taconian-pre-Carboniferous Gaspé Belt: an overview. Bulletin of Canadian Petroleum Geology 49, 186-201.

Donovan, S.K., 1989. The significance of the British Ordovician crinoid fauna. Modern Geology 13, 243-255.

Donovan, S.K., 1991. The taphonomy of echinoderms: calcareous multi-element skeletons in the marine environment. In: Donovan, S.K. (Ed.), The Processes of Fossilization. Belhaven Press, London, 241-269.

Donovan, S.K., 1994. The late Ordovician extinction of the crinoids in Britain. National Geographic Research and Exploration 10, 72-79.

Donovan, S.K., 1995. Pelmatozoan columnals from the Ordovician of the British Isles. Part 3. Monographs of the Palaeontographical Society, London 149 (597), 115-193.

Donovan, S.K., Clark, N.D.L., 1992. An unusual crinoid columnal morphospecies from the Llandovery of Scotland and Wales. Palaeontology 35, 27-35. 
Donovan, S.K., Lewis, D.N., Fearnhead, F.E., Widdison, R.E., 2009. The British Silurian Crinoidea. Part 1, introduction and Disparida. Monographs of the Palaeontographical Society, London 163 (632), 1-45.

Donovan, S.K., Miller, R.F., 2014. The camerate crinoid Scyphocrinites Zenker in the Upper Silurian or Lower Devonian of New Brunswick, Canada. Atlantic Geology 50, 290-296.

Donovan, S.K., Widdison, R.E., Lewis, D.N., Fearnhead, F.E., 2010. The British Silurian Crinoidea. Part 2, addendum to Part 1 and Cladida. Monograph of the Palaeontographical Society, London 164 (634), 47-133.

Donovan, S.K., Widdison, R.E., Lewis, D.N., Fearnhead, F.E., 2012. The British Silurian Crinoidea. Part 3, addendum to parts 1 and 2, Camerata and columnals. Monograph of the Palaeontographical Society, London 166 (638), 135-259.

Fearnhead, F.E., 2008. Towards a systematic standard approach to describing fossil crinoids, illustrated by the re-description of a Scottish Silurian Pisocrinus de Koninck. Scripta Geologica $136,39-61$.

Fearnhead, F.E., Donovan, S.K., 2007. A robust crinoid from the Llandovery (Lower Silurian) of Norbury, Shropshire: systematics, palaeoecology and taphonomy. Proceedings of the Geologists' Association 118, 339-345.

Fortey, R.A., Harper, D.A.T., Ingham, J.K., Owen, A.W., Parkes, M.A., Rushton, A.W.A., Woodcock, N.H., 2000. A revised correlation of Ordovician rocks in the British Isles. Geological Society, Special Report 24, iii+83 pp.

Guensburg, T.E., Sprinkle, J., 2003. The oldest known crinoids (Early Ordovician, Utah) and a new crinoid plate homology system. Bulletins of American Paleontology 364, 1-43.

Holland, C.H., 1971. Silurian faunal provinces? In: Middlemiss, F.A., Rawson, P.F., Newall, G. (Eds.), Faunal Provinces in Space and Time. Seel House Press, Liverpool. Geological Journal Special Issue 4, pp. 61-76. 
Howells, K.D.M., 1975. Palaeoecological study of the Silurian of the Quinn Point section, northern New Brunswick. Unpublished MSc thesis, University of New Brunswick, 323 pp.

McKerrow, W.S., Cocks, L.R.M., 1976. Progressive faunal migration across the lapetus Ocean. Nature $263,304-306$.

Miller, J.S., 1821. A natural history of the Crinoidea or lily-shaped animals, with observations on the genera Asteria, Eurayle, Comatula and Marsupites. C. Frost, Bristol, 150 pp.

Mohibullah, M., Williams, M., Zalasiewicz, J., 2014. Late Ordovician ostracods of the Girvan district, south-west Scotland. Monograph of the Palaeontographical Society, London 167 (640 for 2013), 40 pp.

Moore, R.C., with additions by Ubaghs, G., Rasmussen, H.W., Breimer, A., Lane, N.G., 1978. Glossary of crinoid morphological terms. In: Moore, R.C., Teichert, C. (Eds.), Treatise on Invertebrate Paleontology. Part T. Echinodermata 2(1). Geological Society of America and University of Kansas Press, Boulder and Lawrence, pp. T229, T231, T233-T242.

Noble, J.P.A., 1976. Silurian stratigraphy and paleogeography, Pointe Verte area, New Brunswick, Canada. Canadian Journal of Earth Sciences 13, 537-546.

Noble, J.P.A., Howells, K.D.M., 1979. Early Silurian biofacies and lithofacies in relation to Appalachian Basins in north New Brunswick. Bulletin of Canadian Petroleum Geology 27, 242-265.

Northrop, S.A., 1939. Paleontology and stratigraphy of the Silurian rocks of the Port Daniel - Black Cape region, Gaspé. Geological Society of America, Special Paper 21, 302 pp.

Nowlan, G., 1983. Early Silurian conodonts of eastern Canada. Fossils and Strata 15, 95-110.

Schuchert, C., Dart, J.D., 1926. Stratigraphy of the Port Daniel-Gascons area of southeastern Québec. Geological Survey of Canada, Museum Bulletin 44, 35-58.

Torsvik, T.H., Cocks, L.R.M., 2013. New global palaeogeographical reconstructions for the Early Palaeozoic and their generation. In: Harper, D.A.T., Servais, T. (Eds.), Early Palaeozoic Biogeography and Palaeogeography. Geological Society, London, Memoirs 38, 5-24. 
Ubaghs, G., 1978. Skeletal morphology of fossil crinoids. In: Moore, R.C., Teichert, C. (Eds.), Treatise on Invertebrate Paleontology. Part T. Echinodermata 2(1). Geological Society of America and University of Kansas Press, Boulder and Lawrence, pp. T58-T216.

Van Staal, C.R., Whalen, J.B., Valverde-Vaquero, P., Zagorevski, A., Rogers, N., 2009. PreCarboniferous, episodic accretion-related, orogenesis along the Laurentian margin of the northern Appalachians. In: Murphy, J.B., Keppie, J.D., Hynes, A.J. (Eds.), Ancient Orogens and Modern Analogues. Geological Society, London, Special Publication 327, 271-316.

Wachsmuth, C., Springer, F., 1885. Revision of the Palaeocrinoidea, part III, section 1. Discussion of the classification and relations of the brachiate crinoids, and conclusion of the generic descriptions. Proceedings of the Academy of Natural Sciences of Philadelphia for 1885, 223$364(1-162)$.

Walker, J.A., McCutcheon, S.R., 1995. Siluro-Devonian stratigraphy of the Chaleur Bay Synclinorium, northern New Brunswick. In: Merlini, S.A.A. (Ed.), Current research 1994. New Brunswick Department of Natural Resources and Energy, Minerals and Energy Division, Miscellaneous Report 18, 225-244.

Webster, G.D., 1974. Crinoid pluricolumnal noditaxis patterns. Journal of Paleontology 48, 12831288.

Wilson, R.A., 2013. Geology of the Pointe Verte area (NTS21 P/13), Gloucester and Restigouche counties, New Brunswick. New Brunswick Department of Energy and Mines, Geological Surveys Branch, plate 2013-18.

Wilson, R.A., Kamo, S.L., 2012. The Salinic Orogeny in northern New Brunswick: geochronological constraints and implications for Silurian stratigraphic nomenclature. Canadian Journal of Earth Sciences 49, 222-238. 


\section{Page 15 of 16}

\section{FIGURE CAPTIONS}

Fig. 1. (A) General location map of New Brunswick, eastern Canada, and adjacent territories, showing the geometry of the principal terranes. (B) Geological map of the study area (after Alcock, 1935, fig. 2; Howells, 1975, fig. 2; Wilson, 2013). Specimens described herein were all collected at the study site at Quinn Point $(*)$.

Fig. 2. Field photographs of Lanxocolumnus (col.) chaleurensis sp. nov. at the principal study site at Quinn Point. (A) Densely packed bedding plane preserving myriad columnals; scale in $\mathrm{cm}$. Compare with Fearnhead and Donovan (2007, fig. 1). (B, E) Articular facets and epifacets of two columnals; note the minute, pentastellate lumen in the centre. (C) Pluricolumnal showing separation of columnals with broad epifacets (nodals, probably with two generations of high order internodals) that are obviously separated by lower order internodals (concealed by rock) that lack epifacets. (D) Inner, concave surface of a thecal plate, probably a basal. Scale bars represent $10 \mathrm{~mm}$ except in (A).

Fig. 3. Lanxocolumnus (col.) chaleurensis sp. nov. from the principal study site at Quinn Point; all show articular facet unless stated otherwise. (A) RGM 791 783, articular facet obscured by limestone. (B) RGM 791 782, articular facet obscured by limestone. (C) RGM 791 784, centre of articular facet (in depression) appears tilted, epifacet imperfectly circular (compare with A, B, for example). (D) RGM 791 799, pluricolumnal showing at least two orders of columnal (presumably nodals and priminternodals). (E) RGM 791 792, note small, rounded, central lumen. (F) RGM 791 786, with small, central, pentastellate lumen and crenulae that slope into the depressed articular facet (=internodal). Scale bare represents $5 \mathrm{~mm}$. (G) RGM 791 787, articular facet with moderately large, central lumen and crenulae that extend to the edge of this perforation. All specimens coated with ammonium chloride. Scale bars represent $10 \mathrm{~mm}$ unless stated otherwise. 


\section{Page 16 of 16}

Fig. 4. Lanxocolumnus (col.) geoffnewalli (Fearnhead and Donovan, 2007) comb. nov., Norbury,

Shropshire, England, reconstruction of details of column (after Fearnhead and Donovan, 2007, fig.

4). (A) Pluricolumnal, apparently N212N, with nodals (N) and different orders of internodals $(1,2)$

indicated. Lower orders of internodals may be present within the column, but not apparent

externally. (B) Articular facet and convex latus of nodal reconstructed from external moulds in medium-grained sandstone. At least one specimen described in original paper hinted that the axial canal may have been much more slender than in this interpretation (Fearnhead and Donovan, 2007, fig. 5A); the black shaded 'lumen' was probably the articular facet sensu stricto.

[4121 words; Friday, $9^{\text {th }}$ January 2015.] 


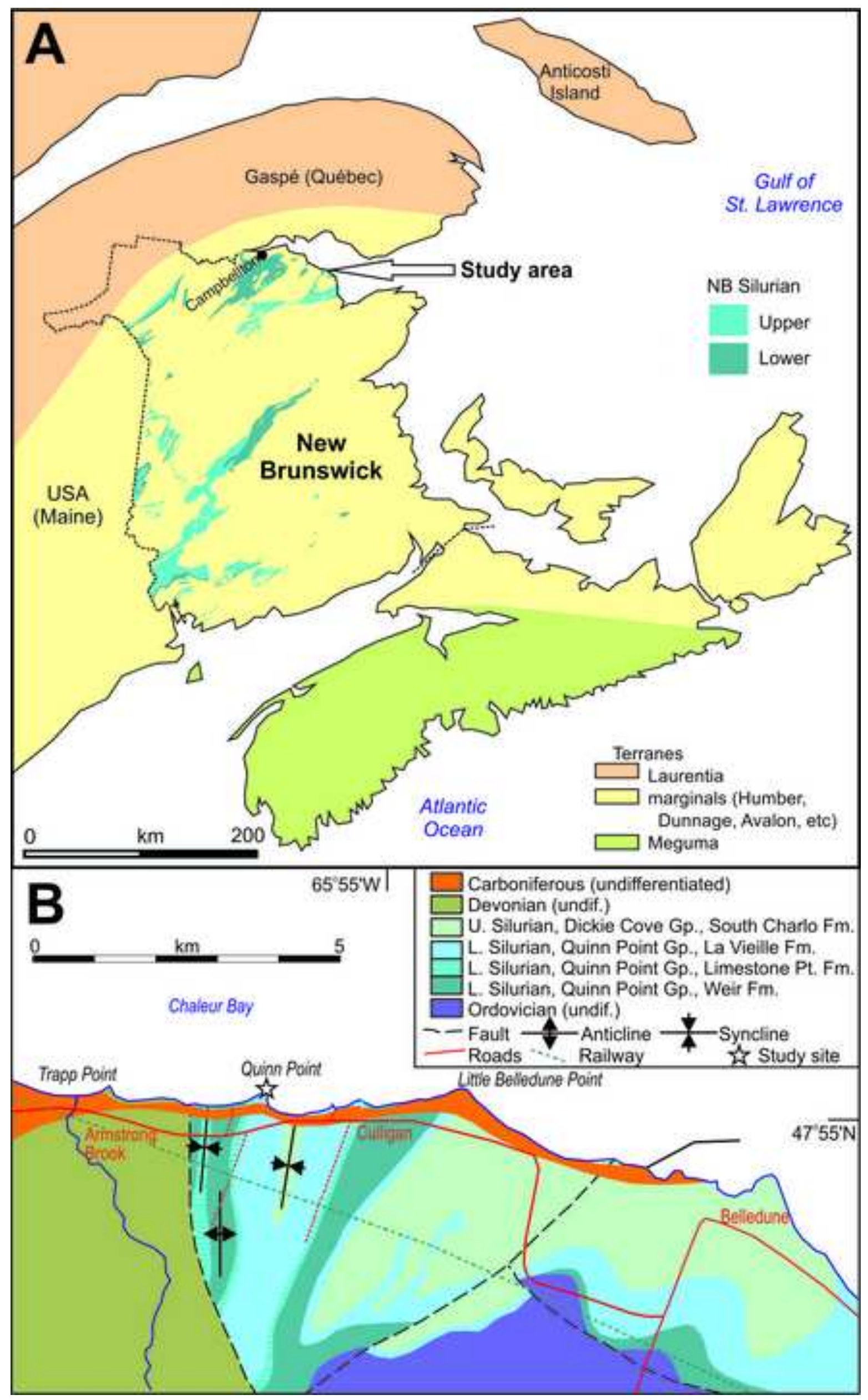



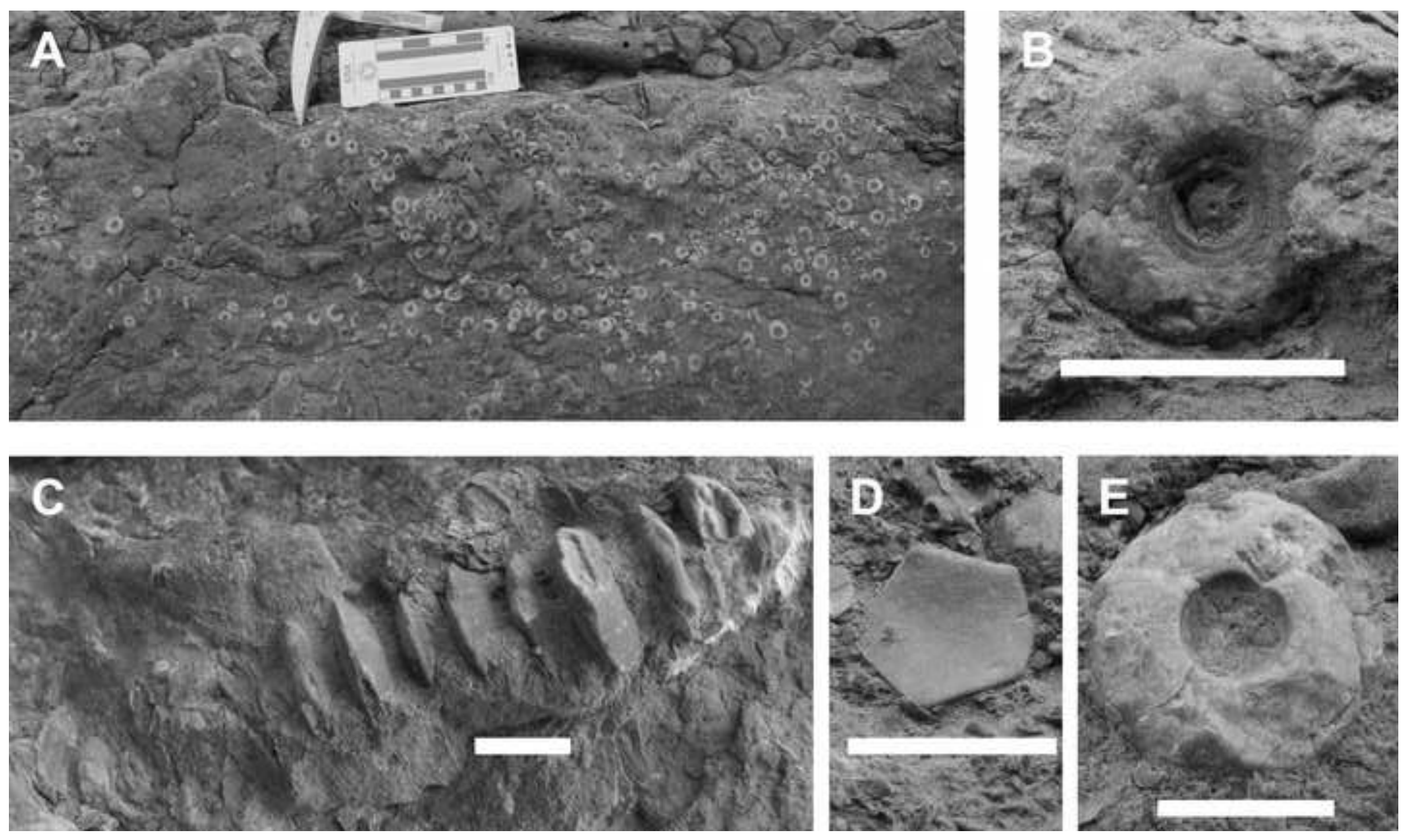


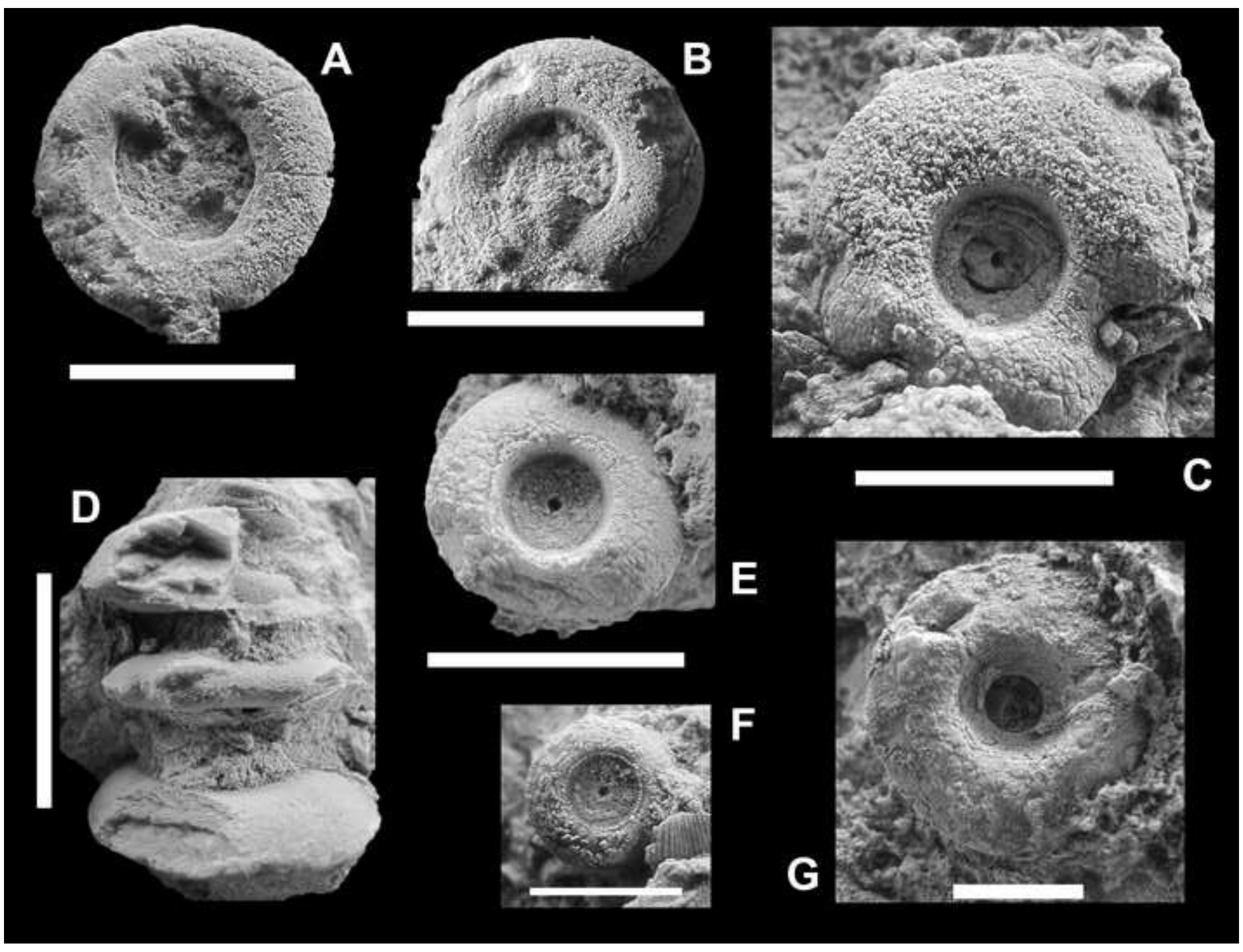



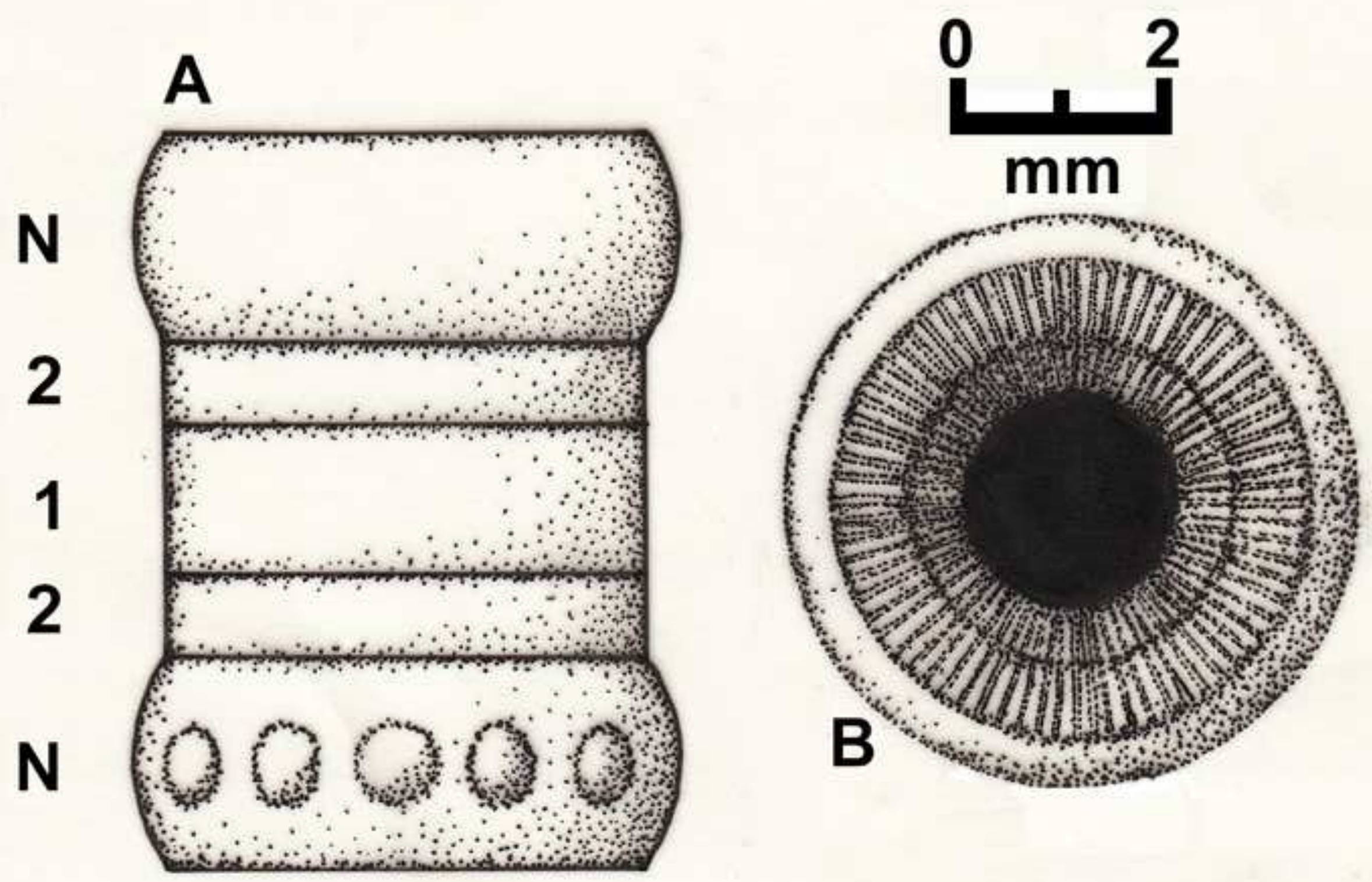